See discussions, stats, and author profiles for this publication at: https://www.researchgate.net/publication/338798056

\title{
Assessment of Renewable Energy in Nigeria: Challenges and Benefits
}

Article $\cdot$ January 2020

DOI: 10.14445/22315381/IJETT-V6811P209

2 authors:

Banji Abubakar Olanipekun

9 publications 7 Citations

SEE PROFILE

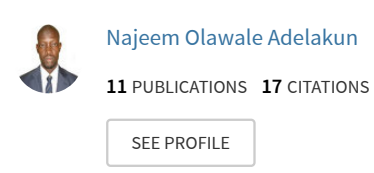

Some of the authors of this publication are also working on these related projects:

Project Host link for the interest of great works View project

Project Easy approach to web development View project 


\title{
Assessment of Renewable Energy in Nigeria: Challenges and Benefits
}

\author{
Banji A. Olanipekun ${ }^{1}$, Najeem O. Adelakun ${ }^{2}$ \\ ${ }^{1} \& 2$ Department of Electrical / Electronic Engineering, The Federal Polytechnic, Ilaro \\ Ogun State, Nigeria.
}

\begin{abstract}
Presently, there is rapid growth in Technology advancement. Developed countries are searching for new alternative energy sources to minimize the pressure on natural sources like gas, uranium, oil, coal, etc. However, natural sources of energy are inadequate and expensive, which also contributed heavily to greenhouse gas emissions. Developing countries like Nigeria are also trying to exploit different renewable energy sources like solar energy, hydropower, wind energy, bioenergy, etc. to accomplish their increasing demand and also to eradicate the energy crisis Nigeria has been experiencing due to insufficient electricity generation. This paper analyses the importance of renewable sources, the challenges and the benefits. This paper also analyses how renewable energy can be accepted as a perfect solution for economic development.
\end{abstract}

Keywords - emission, electricity, economic development, renewable energy, solar energy.

\section{INTRODUCTION}

Nigeria has a population of $203,595,926$ million and her population density is $226 / \mathrm{km}^{2}$ (586 people per $\mathrm{mi}^{2}$ ) of which 351,650 square miles (910,770 square $\mathrm{km}^{2}$ ) is the total land area [17]. The total installed capacity in the grid as of December 2018 was 12,910.40 MW [13], while 2,143 MW is Renewable, of which 2,111 MW is Hydropower [8]. The total exploitable potential of hydropower is estimated at over 14,120 MW, amounting to more than 50,800 GWh of electricity annually [6], over $40 \%$ of her population has no access to electricity [19].

The demand for sustainable energy is rising globally. Thus, renewable energy has been identified as an absolute substitute for fossil fuels in a sustainable and environmentally-friendly way. Predominantly renewable energy is significantly a viable approach to sustainable development to both developed and developing nations. Nigeria over-dependent on depletable oil and gas while neglecting the neverending renewable energy is certainly unjustifiable. Renewable energy is a solution to Nigeria's energy challenges. Aside from being sustainable and inexhaustible, it can be constructed in smaller units, hence, appropriate for rural community management and ownership, and could be crucial to economic development. Renewable energy is a vital element of sustainable development, is essential in reducing greenhouse gas emissions and creates a diversity of energy supply and security.

Nigeria is endowed with rich renewable energy resources that can be used in generating electricity, the substantial ones being solar energy, small and large hydropower, biomass and wind. The Nigerian Electricity Regulatory Commission (NERC) is committed to encouraging investment in renewable energy generation in Nigeria. With huge and mostly untapped potential in renewable energy resources, an obstacle to the development of renewables include the large oil and gas production in the South together with government fuel subsidies, the lack of clarity/market information on private sector opportunities, and a general knowledge gap concerning financial support mechanisms obtainable in the country [16]. Renewable energy provides universal access to sustainable, reliable, affordable and modern-day energy, except for the traditional uses of biomass (e.g. for cooking) which is linked to major negative health impacts.

\section{METHODOLOGY}

To improve the present state of renewable energy resources in the country, the government and power sector should collaborate in solving the nation's power problems. This paper analyses the present state of major renewable energy resources in Nigeria such as solar, large hydro, small hydro, biomass (fuelwood, animal wastes, Agric residues, energy crops) and wind, with its present challenges and the benefits associated with the technology.

TABLE I : Renewable Energy Installed Capacity in Nigeria 2018 (MW)

\begin{tabular}{|l|c|}
\hline Resources & Installed Capacity MW \\
\hline Hydro & 2111 \\
\hline Wind & 3 \\
\hline Solar & 19 \\
\hline Bioenergy & 10 \\
\hline
\end{tabular}

Source: [8] 
TABLE III : Renewable Energy Potentials in Nigeria.

\begin{tabular}{|c|c|c|c|}
\hline & & \multirow{2}{*}{\multicolumn{2}{|c|}{ Remark }} \\
\hline Resource & Potential & & \\
\hline Solar & $\begin{array}{c}3.5 \\
\mathrm{kWh} / \mathrm{m} 2 / \text { day to } \\
7.0 \mathrm{kWh} / \mathrm{m}^{2} / \text { day }\end{array}$ & \multicolumn{2}{|c|}{$19 \mathrm{MW}$ exploited } \\
\hline $\begin{array}{c}\text { Large } \\
\text { Hydropower }\end{array}$ & $11,250 \mathrm{MW}$ & \multicolumn{2}{|c|}{ 1,938.40 MW exploited } \\
\hline $\begin{array}{c}\text { Small } \\
\text { Hydropower }\end{array}$ & 3,500 MW & \multicolumn{2}{|c|}{ 64.20 MW exploited } \\
\hline Wind & $\begin{array}{l}\text { Average of } \\
2-4 \mathrm{~m} / \mathrm{s} \text { at } \\
10 \mathrm{~m} \text { height }\end{array}$ & \multicolumn{2}{|c|}{$3 \mathrm{MW}$ exploited } \\
\hline \multirow[t]{5}{*}{ Bioenergy } & $\begin{array}{l}\text { Municipal } \\
\text { waste }\end{array}$ & $\begin{array}{l}18.5 \text { million } \\
\text { tonnes produced } \\
\text { in } 2005 \text { and } \\
\text { now estimated } \\
\text { at } \\
0.5 \mathrm{~kg} / \mathrm{capita} / \text { day }\end{array}$ & \multirow{5}{*}{$\begin{array}{l}10 \mathrm{MW} \\
\text { exploitec }\end{array}$} \\
\hline & Fuel wood & $\begin{array}{l}43.4 \text { million } \\
\text { tonnes/yr. fuel } \\
\text { wood } \\
\text { consumption }\end{array}$ & \\
\hline & Animal waste & $\begin{array}{l}245 \text { million } \\
\text { assorted animals } \\
\text { in } 2001\end{array}$ & \\
\hline & $\begin{array}{l}\text { Agricultural } \\
\text { residues }\end{array}$ & $\begin{array}{l}91.4 \text { million } \\
\text { tonnes/yr. } \\
\text { produced }\end{array}$ & \\
\hline & Energy crops & $\begin{array}{l}28.2 \text { million } \\
\text { hectares of } \\
\text { arable land; } \\
8.5 \% \text { cultivated }\end{array}$ & \\
\hline
\end{tabular}

Source: [3, 4, 6, 8, 13]

\section{A. Solar}

The solar energy system is the transition of sunlight into electricity, it can be accomplished directly using photovoltaic (PV) panels or indirectly with the aid of concentrated solar power (CSP) [1]. Nigeria has massive energy potential with an annual average total solar radiation of about $12.6 \mathrm{MJ} / \mathrm{m}^{2} /$ day in the coastal latitudes to about $25.2 \mathrm{MJ} / \mathrm{m}^{2} /$ day in the far North [4]. It was reported that Nigeria's first module manufacturing plant had been completed and is now operational with a nameplate capacity of 10 MW [Pvt 2014]. The plant was erected in Sokoto by German firm JVG Thoma [7]. Thus, the National Agency for Science and Engineering Infrastructure (NASENI) and the Sokoto Energy Research Centre (SERC) are now a proud producer of solar panels in the country [4].

The use of solar energy technologies in Nigeria is rising particularly in the areas of street-lighting, water-pumping, rural electrification, refrigeration and powering of communication stations, etc. It may also be used to remote villages not connected to the national grid. It is estimated that $19 \mathrm{MW}$ of solar PV power were operational at the end of 2018 [8].

\section{B. Hydro}

Hydropower energy is generated by building a dam across flowing water to drive turbines which convert mechanical energy into electrical energy. Hydropower is one of the foremost sources of gridpowered generation in Nigeria. Despite its high initial cost, hydropower provides one of the most economical and cleanest sources of electricity. Nigeria is well endowed with large rivers and a few natural falls which are accountable for the high hydropower potential of the country. The Niger and Benue rivers as well as Lake Chad basin with an estimated 1,800 $\mathrm{m} 3$ per capita per year of renewable water resources available in the country [6]. The total exploitable large scale hydropower potential of Nigeria is estimated at over $14,120 \mathrm{MW}$, capable of producing 50,832 GWh of electricity annually. Only about $13.50 \%$ of the nation's large hydropower potential has been tapped. Some of the major hydropower stations are Kainji (760 MW), Jebba (578.40 MW) and Shiroro (600 MW), ongoing Zungeru (700 MW), Mambilla (3050 MW). The Small hydropower potential of Nigeria is estimated at $3,500 \mathrm{MW}$ of which only $64.20 \mathrm{MW}$ which shows that about $1.7 \%$ had been developed [4, 6, 13]. There is an urgent need to develop Small Hydropower Plants for the provision of electricity for the rural areas and remote settlements which will tackle the issue of power deficiency in the country. Presently hydro is the second largest energy resource for electricity generation in the country, contributing about $20 \%$ of the total installed gridconnected electricity generating capacity.

TABLE IIIII : Nigeria Large Hydro Generation Capacities as of December, 2018 (MW)

\begin{tabular}{|l|c|c|c|}
\hline $\begin{array}{c}\text { Power } \\
\text { Station }\end{array}$ & $\begin{array}{c}\text { Availability } \\
\text { Factor } \\
\text { (MW) }\end{array}$ & $\begin{array}{c}\text { Installed } \\
\text { Capacity } \\
\text { (MW) }\end{array}$ & $\begin{array}{c}\text { Average } \\
\text { Availability } \\
\text { (MW) }\end{array}$ \\
\hline Kainji & 0.50 & 760.00 & 382.90 \\
\hline Jebba & 0.75 & 578.40 & 435.82 \\
\hline Shiroro & 0.72 & 600.00 & 434.99 \\
\hline Total & $\mathbf{0 . 6 5}$ & $\mathbf{1 9 3 8 . 4 0}$ & $\mathbf{1 2 5 3 . 7 1}$ \\
\hline
\end{tabular}

Source: [13]

\section{Wind}

Wind renewable energy uses large blades to spin a dynamo inside the turbine which converts mechanical energy into electrical energy. In the far north, the annual average wind speed varies from about $2 \mathrm{~m} / \mathrm{s}$ to about $4 \mathrm{~m} / \mathrm{s}$ at $10 \mathrm{~m}$ heights. Analysis of the wind pattern in the country at $10 \mathrm{~m}$ height shows that some sites have wind regime between 1.0 to $5.1 \mathrm{~m} / \mathrm{s}$. Wind speed ranges from a low $1.4-3.0 \mathrm{~m} / \mathrm{s}$ in the Southern areas and $4.0-5.12 \mathrm{~m} / \mathrm{s}$ in the extreme North $[3,4]$. 
Peak wind speeds usually occur between April and August for most sites. A preliminary study shows that the total actual exploitable wind energy reserve at 10 $\mathrm{m}$ height, may vary from $8.0 \mathrm{MWh} /$ year in Yola to about 51.0 MWh/year in the mountain areas of Jos, Plateau and it can be as high as $97.0 \mathrm{MWh} /$ year in Sokoto. Wind energy has been used for centuries for water pumping as well as for the milling of grains. For the meaningful operation of wind energy, a necessary condition is the optimization of the components of wind water pumping and wind electricity generation.

\section{Bioenergy}

Bio-energy is energy from non-fossil type organic matter referred to as biomass. Biomass is any organic material derived from plants and animals on a renewable basis which includes crops, forage grasses, wood, animal wastes and waste arising from forestry, shrubs, agriculture and municipal and industrial activities. Fuelwood is solid plant biomass that is used for household heating and cooking. Biogas is the product of using biological materials such as plant's oil or animal fats to produce diesel, it can use directly as fuel, or processed into liquids and gases. According to estimates, the daily production of animal waste in Nigeria is about 227,500 tons, which could lead to about 6.8 million $\mathrm{m} 3$ of biogas.

\section{CHALLENGES}

Some vital challenges facing the deployment of renewable energy resources in Nigeria include:

- Low level of public awareness on the availability and usefulness of alternative energy systems;

- Intermittency of resource availability

- High initial starting cost when compared with other conventional energy sources in Nigeria.

- Inadequate fiscal and economic incentives to attract local and foreign investment in alternative energy systems.

- Inadequate policy, regulation and institutional framework for the development and adoption of alternative clean and renewable energy sources.

- Inadequate indigenous human capacity in the design, construction, installation, and maintenance of alternative energy systems.

- Lack of appropriate Standards and quality control for modern technologies.

- Lack of capacity for the local manufacturing of alternative energy system components, resulting in limited supply and higher cost.

\section{BENEFITS}

Some of the key benefits of renewable energy sources in Nigeria include:

- It is Renewable and Sustainable.

- It has low lower carbon emissions and produces little or no air pollution
- It improves energy security by providing greater diversity in the overall energy mix, thereby reducing dependence on the non-renewable energy source.

- A means of providing affordable energy to rural areas without access to the centralized energy system.

- It provides a means of local job creation for the youth and will kick-start new domestic industries that can support the growing international market for renewable energy technologies.

- It is safe, abundant, and clean to use when compared to fossil fuels.

- Several forms of renewable energy exist.

- Renewable energy is a stable source of energy.

\section{RESULTS AND DISCUSSION}

This paper has accessed the major renewable energy sources in' Nigeria, the likely challenges and the numerous benefits. All renewable energy sources should be encouraged wherever there is a high potential for it in the country. The federal government should partner with the private sector to make these clean energy sources available and affordable to most communities in our country.

The result shows that renewable energy contributes about $20 \%$ of the total electricity supply in the nation; however, Fig. 1. Shows that $98.51 \%$ of renewable energy installed in 2018 is from hydro while $1.49 \%$ is from other sources added together such that solar with $0.89 \%$, wind with $0.14 \%$ and bioenergy with $0.47 \%$, there is an urgent need for construction of mini and micro hydropower plant to cater for the supply of electricity to rural and remote location where water is readily available.

Similarly, tapping into the untapped renewable energy resources such as hydro, solar and wind will help in a long way to alleviating the power outage challenges confronting the nation. Also connecting these renewable energy resources to the grid will lead to economic growth which in turn will bring about job creation for the youths in the country.

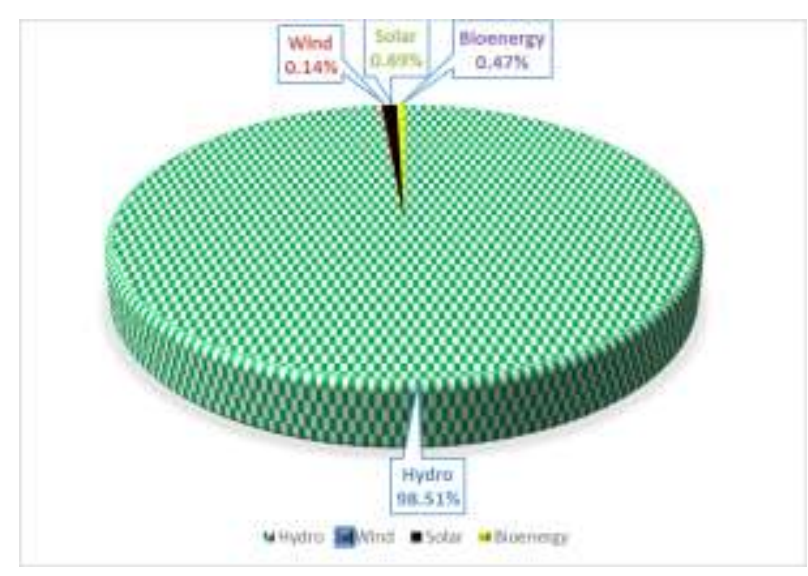

Fig. 1 Percentage of Renewable energy installed capacity in Nigeria 2018 


\section{CONCLUSION}

Having assessed the present state of renewable energy in the country with its likely challenges and benefits, it is evident that renewable energy is the key to clean energy in Nigeria. Tapping into these untapped renewable energy resources such as solar, hydro, wind and biomass will help in eradicating the energy crisis Nigeria has been experiencing due to insufficient electricity generation, and also providing the rural areas and remote location access to electricity without connecting to the grid. Renewable energy technologies can play a key role in the economic development of the nation if all the untapped resources are tapped and effectively utilized, there should also be an adequate incentive to producers, developers, and suppliers of solar, wind and biomass energy product and services to increase productivity. Proper energy efficiency culture should be embraced to boost the nation's energy needs and as well provides the foundation for energy independence.

\section{REFERENCES}

[1] Adelakun, N. O. and Olanipekun, B. A. "A Review of Solar Energy," Journal of Multidisciplinary Engineering Science and Technology (JMEST), Vol. 6 Issue 12, December 2019.

[2] Agbetuyi A. F, Oyedepo S. O, Awosope C. O. A, Orovwode H. E, and Olowoleni J. O, "The Vast Renewable Energy in Africa versus its Slow Pace of Harnessing," International Electrical Engineering Journal (IEEJ) Vol. 8, No 2, Pp 2507 - 2512, 2018.

[3] ECN, 'Draft National Renewable Energy and Energy Efficiency Policy (NREEEP)," Energy Commission of Nigeria, Abuja Nigeria, 2014.

[4] ECN, 'National Energy Policy [Draft Revised Edition]," Energy Commission of Nigeria, Abuja Nigeria. 2018.

[5] Ezugwu, C. N. "Renewable Energy Resources in Nigeria: Sources, Problems and Prospects," Journal of Clean Energy Technologies, Vol. 3, No. 1, 2015.

[6] IHA, "hydropower status report, sector trends and insights," International Hydropower Association, London, United Kingdom.

[7] Jäger-Waldau, A., "PV Status Report 2019, EUR 29938 EN," Publications Office of the European Union, Luxembourg, 2019.

[8] IRENA, Renewable capacity statistics 2019, International Renewable Energy Agency (IRENA), Abu Dhabi, 2019.

[9] IRENA, "IRENA Planning and prospects for renewable power: West Africa, International Renewable Energy Agency," Abu Dhabi, 2018.

[10] Okoye, C. U. \& Adelakun, N. O. "Design and Evaluation of Electrical Services for an Energy Efficient Home," Iconic Research and Engineering Journals, Vol. 3, Issue 6, Pp 95 102, Dec 2019.

[11] REN21, "Renewables 2019 Global Status Report, (Paris: REN21 Secretariat)," 2019.

[12] TCN "Transmission Company of Nigeria: Grid System Operations," Annual Technical Report, National Control Centre, Osogbo, Nigeria, 2018.

[13] The Nigerian Energy Sector "An Overview with a Special Emphasis on Renewable Energy," Energy Efficiency and Rural Electrification 2nd Edition, June 2015.

[14] https://nerc.gov.ng/index.php/home/operators/renewableenergy [Accessed December 9, 2019]

[15] https://www.get-invest.eu/marketinformation/nigeria/renewable-energy-potential [Accessed November 17, 2019]
[16] https://www.worldometers.info/world-population/nigeriapopulation [Accessed January 5, 2020]

[17] https://nairametrics.com/2017/11/13/wind-energy-choice energy-generation-nigeria [Accessed December 8, 2019]

[18] https://energypedia.info/wiki/Nigeria_Energy_Situation [Accessed November 8, 2019] 